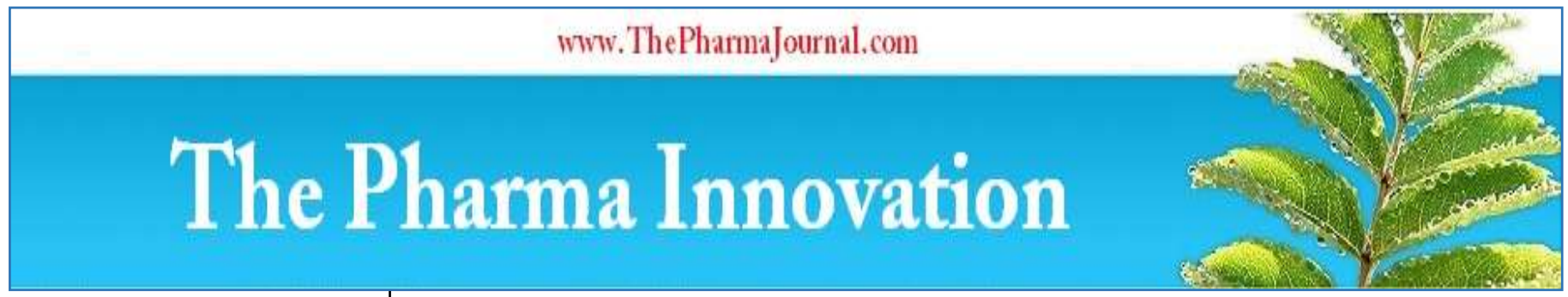

ISSN (E): 2277 - 7695

ISSN (P): 2349-8242

NAAS Rating: $\mathbf{5 . 0 3}$

TPI 2021; 10(2): 541-546

(C) 2021 TPI

www.thepharmajournal.com

Received: 20-11-2020

Accepted: 11-01-2021

\section{K Radhika}

Department of Soil Science and Agricultural Chemistry, TNAU, Coimbatore, Tamil Nadu, India

S Meena

Department of Soil Science and Agricultural Chemistry, TNAU, Coimbatore, Tamil Nadu, India

\title{
Effect of zinc on growth, yield, nutrient uptake and quality of groundnut: A review
}

\section{K Radhika and S Meena}

DOI: https://doi.org/10.22271/tpi.2021.v10.i2h.5727

\section{Abstract}

Among the nine oilseed crops, groundnut is an important edible oilseed crop of our country and edible oil economy primarily depends upon groundnut production. $\mathrm{Zn}$ deficiency in Indian soils is likely to increase from 49 to $63 \%$ by 2025 . India is leading in groundnut acreage but behind the China in production due to less productivity. Apart from rain dependent cultivation and mineral nutrition play a vital role in groundnut productivity. Among the nutrients, $\mathrm{Zn}$ deficiency cause yield loss to the maximum of $40 \%$ in groundnut. The average response of groundnut to zinc fertilization ranged from 210 to $470 \mathrm{~kg} \mathrm{ha}^{-1}$. Hence, it is ideal to follow suitable crop improvement and agronomic management strategies to enhance the uptake and availability of $\mathrm{Zn}$ in peanut. Keeping in view the above facts, the present review reveals the effect of zinc on growth, yield, nutrient uptake and quality of groundnut.

\section{Keywords: Groundnut, zinc, zinc content, uptake, yield}

\section{Introduction}

Groundnut (Arachis hypogaea L.) is an important oilseed and supplementary food crop of the world. It is fourth most important source of edible oil and third most important source of vegetable protein. It belongs to family Leguminaceae. It is premier oilseed crop of India popularly known as peanut, monkey nut, manila nut. India ranks first in respect of area and second in production after China. Globally, the crop is raised on 26.4 million hectares with a total production of 37.1 million MT. In India, it is cultivated over an area of 4596.33 in hectares with production of 6733.33 MT. The average productivity is $1400 \mathrm{~kg} / \mathrm{ha}$ (Anon, 2017). India accounts for about 27 per cent of global area and contributes 19 per cent to world groundnut production (Rai et al., 2016) ${ }^{[24]}$. Tamil Nadu ranks fourth in terms of groundnut area (4.419 lakh ha) and third in production (9.737 lakh tonnes) (Singh, 2014) [25, 32, 35]. Globally, $50 \%$ of groundnut is used for oil extraction, $37 \%$ confectionary and $12 \%$ for seed purpose (Nurezannat et al., 2019).

Zinc known to be the constituent of enzyme and also involved in synthesis of pyruvic decarboxylase and indole acetic acid. Zinc is required in various metabolic processes as catalysts. Zinc also increases the content of protein, calorific value, amino acid and fat in oilseed crop. Zinc catalyses the process of oxidation in plant cells and is vital for transformation of carbohydrates, regulates the consumption of sugar, increases source of energy for the production of chlorophyll, aids in the formation of auxin and promotes absorption of water.

Zinc deficiency start yellowing of leaves from lamina to base, mid-rib and veins remain green. Later on necrotic brown spots are developed and dorsal leaf veins become brown. The deficiency of zinc affects IAA synthesis and delay dehydrogenase enzyme activity leading to poor plant metabolic activity. Balanced fertilization helps to improve the quality of the produce. Thus, use of fertilizer for a particular crop should be considered from quality point of view. Zinc is an important micronutrient reported deficient in Indian soils. As a part of balance nutrition an adequate supply of micronutrient especially of $\mathrm{Zn}$ is of paramount importance. Zinc deficiency in crop plants is a widespread nutritional disorder in a variety of soils. Soils being low in zinc status $(0.5 \mathrm{ppm})$, it is assumed that application of micronutrient may increase the productivity of groundnut due to its multifarious role in plant metabolism. Thus, proper plan nutrition is an important factor for improving yield and quality of crop. As balanced fertilization support the demands of plant by regulating the metabolic processes in yield formation towards quality. Ultimately, it is not only the consumer who will benefit; it is also the farmer through higher income and the nation with export opportunity. As its aim is for achieving maximum returns and maintenance of soil fertility.

$$
\sim 541 \sim
$$


Now days, country is facing edible oil crisis as well as increasing population demand for edible oil. Thus to overcome this challenges suitable and improved techniques for groundnut production should be adopted by farmer. This paper reviews the effect of zinc on growth, yield, nutrient uptake and quality of groundnut.

\section{Effect of zinc on growth characters \\ Root characteristics}

Malewar et al., (1993) ${ }^{[14]}$ reported that zinc fertilization to groundnut up to $20 \mathrm{~kg} \mathrm{ha}^{-1}$ showed significantly enhanced root characters like root growth, root volume and root density Bagal et al., (2006) ${ }^{[4]}$ reported that root growth of groundnut crop was significantly influenced with the application of ZnSC>4 @ $20 \mathrm{~kg} \mathrm{ha}^{-1}$. Maharnor et al., (2018) ${ }^{[12,13]}$ studied that application@ $30 \mathrm{~kg} \mathrm{ha}^{-1}+\mathrm{RDF}$ recorded maximum root length and develops rapidly during early vegetative growth stage and younger roots are found most active for absorption and transport of nutrient as zinc application could be attribute to unhindered auxin synthesis in plant.

\section{Nodulation activity}

Tripathy et al., (1999) ${ }^{[37]}$ reported that application of zinc to groundnut cultivar JL-24 and TGS-1 significantly increased nodulation. Bagal (2006) [4] reported that application of $\mathrm{ZnSC}>4$ at die rate of $20 \mathrm{~kg} \mathrm{ha}^{-1}$ Recorded maximum nodulation in groundnut at most active growth stage of crop i.e. (45DAS). Sharma et al., (2013) ${ }^{[34]}$ reported that number of nodules significantly increased with the application of zinc up to $5 \mathrm{~kg} \mathrm{ha}^{-1}$. Mondal et al., (2006) [18] studied the application of micronutrient: Zn, Fe, B, Mo, and mixed @ 2 ppm/pot and@1 kg/ha in field as their salt along with basal doses of NPK (30: 60:40) significantly increasing nodulation, and $\mathrm{N}$ - fixation in soybean. These might be due to role of $\mathrm{Zn}$ and Mo in enzymes activities as they are essential constituent of N2 fixing enzymes complex "nitrogenase" which are responsible for increase in leghemagloubin which ultimately increase nodulation and $\mathrm{N}$ - fixation in soybean. Maharnor et al., (2018) ${ }^{[12,13]}$ observed that the Cultivar JL-24 with $\mathrm{ZnSO}_{4}$ application@30 kg ha $\mathrm{kg}^{-1}+\mathrm{RDF}$ recorded maximum nodule number of groundnut at most active growth stage of crop i.e. (45 DAS). The increase in nodulation could be due to enzymatic activity and auxin synthesis.

\section{Effect of zinc on nutrient availability of soil nutrients}

Vyas et al., (2003) ${ }^{[39]}$ observed that application of Zn @ $5 \mathrm{~kg}$ $\mathrm{ha}^{-1}$ and 10 t FYM ha-1 increased NPK contents by soybean seed over control. The content of NPK in soybean seed was higher due to synergistic effect of applied nutrient. As zinc play important role enzymatic activities which help in root development and FYM increases the availability of nutrient thus increases uptake cause increase content of nutrient of seed. Nadaf and Chidanandappa $(2015)^{[16,20,21]}$ recorded that the application of zinc sulphate@ 20 kg ha ${ }^{-1}+$ borax @ $5 \mathrm{~kg}$ ha $^{-1}$ increses N, P, K, S and Zn content in haulm and kernel of groundnut. This might be due to the enhanced root development, uptake and translocation of nutrient in plant in presence of zinc and boron.

Maharnor et al., $2018^{[12,13]}$ studied the application of $\mathrm{ZnSO}_{4}$ @ $30 \mathrm{~kg} \mathrm{ha}^{-1}+\mathrm{RDF}$ increases concentration of NPK and $\mathrm{Zn}$ in kernel and haulm at harvest in cultivar JL-24 because of maximum growth of root and root nodules which ultimately increases absorption of nutrient. Sharma et al., (2011) [34] observed that application of 100 per cent NPK and zinc increased the availability of nitrogen, phosphorus, potassium and zinc content of soil. Shanna et al., (2011) observed that application of 100 per cent NPK and zinc to groundnut increased the availability of phosphorus in soil. Laharia et al., $(2015)^{[11]}$ recorded that the application of $150 \% \mathrm{RDP}+5 \mathrm{~kg}$ $\mathrm{Zn} \mathrm{ha}{ }^{-1}$ to soybean increased phosphorus availability in soil. Laharia et al., (2015) ${ }^{[11]}$ recorded that the application of $150 \% \mathrm{RDP}+5 \mathrm{~kg} \mathrm{Zn} \mathrm{ha}{ }^{-1}$ to soybean increased nitrogen availability in soil. Elayaraja et al., (2014) ${ }^{[30]}$ reported that application of $\mathrm{ZnSO}_{4}$ at $30 \mathrm{kgha}^{-1}+150$ per cent RDF to groundnut increased nitrogen availability in soil.

\section{Potassium availability}

Shanna et al., (2011) observed that application of 100 per cent NPK and zinc to groundnut increased the availability of potassium in soil. Laharia et al., (2015) ${ }^{[11]}$ recorded that the application of $150 \% \mathrm{RDP}+5 \mathrm{~kg} \mathrm{Zn} \mathrm{ha}^{-1}$ in soybean increased potassium availability in soil. Elayaraja et al., (2014) [30] reported that application of Z11SO4 at $30 \mathrm{kgha}^{-1}+150$ per cent RDF to groundnut increased potassium availability in soil.

\section{Zinc availability}

Sharma et al., (2011) ${ }^{\text {[34] }}$ observed that application of 100 percent NPK and zinc increased the availability of nitrogen, phosphorus, potassium and zinc content of soil. Arunachalam et al., (2013) ${ }^{[1]}$ studied and reported that basal application of $\mathrm{Zn}$ and $\mathrm{Fe}$ enhance the soil available $\mathrm{Zn}$ and $\mathrm{Fe}$ content application of micronutrient increased the kernel $\mathrm{Zn}$ content to an average of $28.7 \%$ and pod yield of $12.6 \%$ in groundnut cultivars. Kumbhar et al., (2017) ${ }^{[10]}$ reveled that application of RDF+20 kg ha- $1 \mathrm{ZnSO}_{4}+20 \mathrm{~kg} \mathrm{ha}^{-1}$ EDTA FeSO4+2 kg $\mathrm{ha}^{-1}$ Borax showed significant effect on nutrient availability. The availability of $\mathrm{Zn}$ was maximum with application of micronutrient at different growth stages of sunflower over control. As it was ranged from 1.85 to $0.87 \mathrm{ppm}$. The periodical availability of zinc in soil from 35 days to harvest showed decreasing trend with advancement of time. This decrease in available zinc in soil may be associated with the utilization of available zinc by crop. Maharnor et al., (2018) $[12,13]$ reported that the nutrient availability was significantly influenced with application of treatment. The availability of NPK and Zn was maximum in cultivar JL-24 with $\mathrm{ZnSO}_{4}$ @ $30 \mathrm{~kg} \mathrm{ha}^{-1}+\mathrm{RDF}$ (3 stages). The nutrient availability of all the four nutrients was initially higher and gradually decreased from flowering to pod formation stage of groundnut.

\section{Effect of zinc on nutrient uptake viz. N, P, K and Zn}

Babhulkar et al., (2000) ${ }^{[3]}$ reported that application of zinc up to $15 \mathrm{~kg} \mathrm{ha}^{-1}$ increase zinc concentration both in kernel and haulm. Vyas et al., (2003) ${ }^{[39]}$ observed that application of $\mathrm{Zn}$ @ $5 \mathrm{~kg} \mathrm{ha}^{-1}$ increased NPK contents and uptake by soybean seed. Nutrient uptake i.e. NPK of control was 75.75, 26.06 and $61.20 \mathrm{~kg} \mathrm{ha}^{-1}$, respectively and NPK uptake of plot receiving Zn@ $5 \mathrm{~kg} \mathrm{ha}^{-1}$ was $84.35,29.02$ and $68.16 \mathrm{~kg} \mathrm{ha}^{-1}$, respectively. Singh et al., (2006) ${ }^{[25,32,35]}$ reported that zinc uptake by pod of groundnut increased significantly with increasing level of zinc compared to control. Among die zinc levels $5.0 \mathrm{~kg} \mathrm{ha}^{-1}$ recorded the highest uptake of zinc $(96.7$ gm. ha $\left.{ }^{-1}\right)$. Singaravel et al., (2006) [6, 30] reported that application of micronutrient with the recommended NPK and $25 \mathrm{~kg}$ zinc sulfate $\mathrm{ha}^{-1}$ gave the highest values for $\mathrm{N}, \mathrm{P}, \mathrm{K}$ and Zn uptake in groundnut. Elayaraja and Singaravel $(2012)^{[6,30]}$ reported that 150 per 
cent NPK + $\mathrm{ZnSO}_{4} @ 30 \mathrm{~kg} \mathrm{ha}^{-1}+$ borax @ $15 \mathrm{~kg} \mathrm{ha}^{-1}$ recorded the highest $\mathrm{N}$ (85.05 and $\left.68.85 \mathrm{~kg} \mathrm{ha}^{-1}\right), \mathrm{P}$ (11.89 and $\left.14.23 \mathrm{~kg} \mathrm{ha}^{-1}\right)$ and $\mathrm{K}\left(36.83\right.$ and $\left.73.65 \mathrm{ha}^{-1}\right)$ uptake in pod and haulm, respectively. The increased uptake of major nutrients was mainly due to the fact that the micronutrients like zinc and boron are involved in nitrogen fixation and translocation into plant parts, which might have led to higher dry matter production. The higher nitrogen absorption may also be due to stimulatory effect of zinc and boron on nitrogen uptake. The higher $\mathrm{P}$ uptake may be due to the solubilization of native phosphorus by the organic acids in addition to applied fertilizers which ultimately resulted in better root growth and increased physiological activity of roots to absorb more phosphorus. Increased $\mathrm{K}$ uptake might be due to better plant growth leading to higher uptake of nutrients and further on the stimulatory effect of $\mathrm{B}$ and $\mathrm{Zn}$ in absorption of potassium.

Nadaf and chindanandappa $(2015)^{[16,20,21]}$ who reported that the application of zinc sulphate at three levels viz. 5, 10 and $20 \mathrm{~kg}$ ha'1 zinc increased the nitrogen concentration in the haulm. Bagal (2006) ${ }^{[4]}$ reported that application of zinc @ 20 $\mathrm{kg} \mathrm{ha}^{-1}$ increased zinc concentration both in haulm and kernel. Tathe et al., (2008) ${ }^{[38]}$ studied that zinc application of $40 \mathrm{~kg}$ ha1 recorded significantly the highest zinc uptake by groundnut. Elayaraja et al., (2012) [30] reported that application ZnS04 @ $30 \mathrm{~kg} \mathrm{ha}^{-1}$ significantly increase nutrient uptake by groundnut. Suresh et al., (2013) ${ }^{[36]}$ reported that application of zinc @ $10 \mathrm{~kg} \mathrm{ha}^{-1}$ uptake on an average, one ton of oilseed yield leads to 45 to $150 \mathrm{~g}$ uptake of $\mathrm{Zn}$. Saha et al., (2015) ${ }^{[29]}$ reported that the application of $\mathrm{Zn}$ significantly increased their nutrient uptake in kernel. On an average $\mathrm{Zn}$ uptake by groundnut ranged from 0.14 to $0.40 \mathrm{~kg} \mathrm{ha}^{-1}$ respectively. Noman et al., (2015) ${ }^{[19]}$ reported that application of $2.5,5.0$, and $7.5 \mathrm{~kg}^{-1} \mathrm{Zn}$ result in $45.5 \mathrm{Zn}$ - uptakes in kernel over control.

\section{Effect of zinc on kernel and haulm yield of groundnut}

Chitdeshwari et al., (2003) ${ }^{[5]}$ reported that soil application of $\mathrm{Zn} 5 \mathrm{~kg} \mathrm{ha}^{-1}$ significantly increased the pod yield of groundnut the tune of $24.2 \%$ for TMV 7 and $14,8 \%$ for JL-24

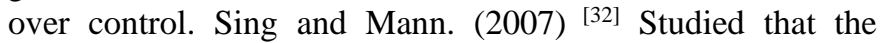
application of $5 \mathrm{~kg} \mathrm{Zn} \mathrm{ha-1}$ significantly increased the pod yield of groundnut (2251 kgha-1). Saren et al., (2007) [31] recorded that the application of zinc @ $20 \mathrm{~kg} \mathrm{ha}^{-1}$ significantly higher pod yield $\left(18 \mathrm{q} \mathrm{ha}^{-1}\right)$, kernel yield $\left(13 \mathrm{q} \mathrm{ha}^{-1}\right)$ in groundnut. Bairagi et al., (2007) [2] recorded that the application of zinc@10 kg ha ${ }^{-1}$ and phosphorus@ $95 \mathrm{~kg} \mathrm{ha}^{-1}$ significant increase in grain and straw yield of soybean. Tathe et al., (2008) ${ }^{[38]}$ studied and reported that zinc application, 40 $\mathrm{kg} \mathrm{ha}^{-1}$ recorded significantly the highest pod yield, protein content and zinc uptake by groundnut.

Sonawane et al., (2010) ${ }^{[33]}$ studied and was observed that significantly highest pod yield was recorded in $20 \mathrm{~kg} \mathrm{ZnSO}_{4}$ soil application with RDF. Thakur et al., (2010) ${ }^{[40]}$ the study revealed that application of $25 \mathrm{~kg}$ of $\mathrm{ZnSO}_{4} \mathrm{ha}^{-1}$ along with recommended dose of fertilizer 25:50 kg N and $\mathrm{P}$ ha-1 has given significantly higher dry pod yield, and haulm yield. Nadaf and Chidanandappa et al., $(2011)^{[16,20,21]}$ reported that pod and haulm yield of groundnut was significantly increased over the control due to application of zinc sulphate at three level 5,10 and $20 \mathrm{~kg} \mathrm{ha}^{-1}$.

Reddy et al., (2011) ${ }^{[26]}$ reported that the yield attributes of groundnut i.e. pod $\left(2592 \mathrm{~kg} / \mathrm{ha}^{-1}\right.$ and haulm yield $(4426 \mathrm{~kg}$ ha $\left.{ }^{1}\right)$ were found to be the highest with $60-80-100 \mathrm{~kg} \mathrm{ha}^{-1}$ along with application of four micronutrient application $(\mathrm{Zn}, \mathrm{B}, \mathrm{Fe}$ and $\mathrm{Cu}$ ). Involvement of boron in catalyzing the metabolism of carbohydrates and $\mathrm{Fe}$ and $\mathrm{Zn}$ increases enzyme activity and other biological activity ultimately increase yield due absorption of nutrient.

Elayaraja et al., (2012) ${ }^{[30]}$ reported that application of ZnS04 @ $30 \mathrm{~kg} \mathrm{ha}^{-1}$ application significantly increased pod yield of $2466 \mathrm{~kg}$ ha4 and haulm yield of $3354 \mathrm{~kg} \mathrm{ha}^{-1}$. Which represented 31.31 and $25.95 \%$ increase in pod and haulm yield. Elayaraja D and Singaravel R. $(2012)^{[6,30]}$ observed that the application of $150 \% \mathrm{NPK}+\mathrm{ZnSO}_{4} @ 30 \mathrm{~kg} \mathrm{ha}^{-1}+$ borax @ $15 \mathrm{~kg} \mathrm{ha}^{-1}$ along with 150 per cent NPK recorded the higher pod yield (2466 $\mathrm{kg} \mathrm{ha}^{-1}$ ) and haulm yield (3354 kg ha$\left.{ }^{1}\right)$ this might be due to $\mathrm{Zn}$ and $\mathrm{B}$ through activation of various enzymes and increased basic metabolic rate in plants, facilitated the synthesis of nucleic acids and hormones, which in turn enhanced the pod yield due to greater availability of nutrients and photosynthates. Bhadauria et al., (2012) [4] studied and reported that application of $\mathrm{Zn}$ at $10 \mathrm{~kg} \mathrm{ha}^{-1}$ increase grain and stover yield of mustard.

Suresh et al., (2013) ${ }^{[36]}$ reported that application of Z11S04 at $5 \mathrm{~kg}$ ha with recommended dose of NPK showed significantly highest pod yield of groundnut. Sharma et al., (2013) [34] studied and reported that varying levels of zinc on growth and yield of groundnut varieties and recorded that the pod per plant, kernel per pod, pod yield, haulm yield, etc. significantly increased with the application of $\mathrm{Zn}$ up to $5 \mathrm{~kg} \mathrm{ha}$. Sara et al., (2013) ${ }^{[27]}$ Reported that highest yield of groundnut was achieved with applying 60kghal nitrogen and $3 \mathrm{~g} \mathrm{ha}^{-1}$ zinc.

Elayaraja D (2014) ${ }^{[30]}$ recorded the highest pod yield of 2466 $\mathrm{kg} \mathrm{ha}^{-1}$ and haulm yield of $3354 \mathrm{~kg} \mathrm{ha}^{-1}$ at $150 \%$ NPK along with $\mathrm{ZnSO}_{4} @ 30 \mathrm{~kg} \mathrm{ha}^{-1}$ and borax @ $15 \mathrm{~kg} \mathrm{ha}^{-1}$ with composted coirpith as compared $100 \%$ recommended NPK alone 1878 and $2663 \mathrm{~kg} \mathrm{ha}^{-1}$ of pod and haulm yield respectively. Rahevar et al., (2015) ${ }^{[23]}$ reported that the application of FYM@ $5 \mathrm{t} \mathrm{ha}^{-1}$ with $5 \mathrm{~kg} \mathrm{Fe} \mathrm{ha-1}+4 \mathrm{~kg} \mathrm{Zn} \mathrm{ha}{ }^{-1}$ to groundnut considerably increased yield, yield attributes and quality parameters. Saha et al., (2015) ${ }^{[29]}$ studied on Zn, B and $\mathrm{S}$ on the yield and quality of groundnut. Reported that the basal application of Zn @ 5 and $10 \mathrm{~kg} \mathrm{ha}^{-1}$ caused an increase in nut yield by $3.7 \%$ and $28.3 \%$ respectively over control.

Gowthami and Ananda (2017) ${ }^{[8]}$ studied the effect of soil application of $\mathrm{ZnSO}_{4} @ 25 \mathrm{~kg} \mathrm{ha}^{-1}+$ foliar application of $\mathrm{ZnSO}_{4} @ 0.5 \%$ recorded significantly higher kernel (2051 kg $\mathrm{ha}^{-1}$ ) and haulm yield $\left(3080 \mathrm{~kg} \mathrm{ha}^{-1}\right)$. This was due to favorable effect of higher dry matter production and cumulative effective effect of yield attributes. Rabari et al., (2018) ${ }^{[22]}$ observed that application of $\mathrm{ZnSO}_{4} @ 8 \mathrm{~kg} \mathrm{ha}^{-1}+$ Foliar Spray of FeSO4 @ 1\% significantliy increased the haulm and pod yield in groundnut. It might be due to improvement in nutrient uptake particularly iron and zinc that increased transformation of photosynthetic activity towards growing plant parts.

\section{To study the effect of zinc on quality of groundnut kernels Oil content}

Saini et al., (1976) ${ }^{[28]}$ studied the effect of micronutrients (Zn, $\mathrm{Mn}, \mathrm{Mo}, \mathrm{Cu}, \mathrm{Fe}$ and $\mathrm{B}$, at rates of 11, 20, 1, 11, 20 and $2 \mathrm{~kg}$ ha*1 respectively) on the yield and quality of groundnut cultivar M 145, the application of micronutrients in addition to NPK increased oil content (1.25-2.45\%), and total oil yield (7.8- 21.8\%) compared with those of control plants (NPK only). Ramlal et al., (1990) ${ }^{[25]}$ reported that increase oil and protein content of groundnut due to the application of zinc sulphate. Malewar et al., (1992) ${ }^{[14]}$ studied on inorganic 
mineral matter and quality of grains as influenced by zinc levels in peanut cultivars, reported that the Zinc application up to $20 \mathrm{~kg} \mathrm{ha}^{-1}$ improve the content of ash, N, K, Ca, Zn and $\mathrm{Fe}$ in grain legume further, significant accumulation of proteins and soluble carbohydrates in peanut cultivars were recorded due to zinc application. Krishnappa et al., (1994) [9] revealed that application of $\mathrm{N}, \mathrm{P}, \mathrm{K}$ and $\mathrm{Zn}$, had significantly increased seed oil content in groundnut

Tathe et al., (2008) ${ }^{[38]}$ studied the effect of zinc on groundnut in vertisol, as regards zinc application, $40 \mathrm{~kg} \mathrm{ha}^{-1}$ recorded significantly the highest pod yield, protein content and zinc uptake by groundnut.

Nadaf and Chidanandappa $(2011)^{[16,20,21]}$ reported that that crude protein content, oil content and oil yield of groundnut was significantly increased over the control due to application of zinc sulphate at three level 5,10 and $20 \mathrm{~kg} \mathrm{ha}^{-1}$. Suresh et al., (2013) ${ }^{[36]}$ reported that application of $\mathrm{ZnSO}_{4}$ at $5 \mathrm{~kg} \mathrm{ha}^{-1}$ $+\mathrm{FeSO}_{4}$ at $10 \mathrm{~kg} \mathrm{ha}^{-1}+$ boron at $1 \mathrm{~kg} \mathrm{ha}^{-1}$ with recommended dose of NPK showed significantly highest pod yield, oil content and protein content of groundnut significantly increased. Saha et al., (2015) ${ }^{[29]}$ studied effect of $\mathrm{Zn}, \mathrm{B}$ and S on the yield and quality of groundnut, and reported that the basal application of $\mathrm{Zn}, \mathrm{S}$ and B showed a positive interaction as yield increase with their uptake in groundnut and oil content in nuts ranged from 45.3 to $54.4 \%$. Meena et al., $(2007)^{[11,15]}$ studied effect of secondary and micronutrient for groundnut and reported that the application of $\mathrm{ZnSO}_{4}$ @ $20 \% /+0.5 \%$ foliar spray along with borax @ $25 \mathrm{~kg} \mathrm{ha}^{-1}+0.2$ $5 \%$ foliar spray recorded the highest pod, kernel and oil yield. Saren et al., (2007) ${ }^{[31]}$ studied the effect of application of zinc @ $20 \mathrm{~kg} \mathrm{ha}^{-1}$ significant increased the oil yield $(620.1 \mathrm{~kg} / \mathrm{ha})$ and oil content as compared to 15 and $25 \mathrm{~kg} \mathrm{ha}^{-1}$ in groundnut. Zn @ $25 \mathrm{~kg} \mathrm{ha}^{-1}$ lowered the oil yield might be due to toxicity of zinc. The result for increases in oil content and oil yield may be due to $\mathrm{Zn}$ play vital role in groundnut production as it is an essential component of enzymes help in synthesis of amino acid. Bairagi et al., (2007) ${ }^{[2]}$ reported the effect of application of zinc @ $10 \mathrm{~kg} \mathrm{ha}^{-1}$ and phosphatic fertilizer @ $75 \mathrm{~kg} \mathrm{ha}^{-1}$ recorded significantly maximum oil content in soybean. Thakur et al., (2010) ${ }^{[40]}$ revealed that the application of $25 \mathrm{~kg}$ of $\mathrm{ZnSO}_{4} \mathrm{ha}^{-1}$ along with RDF 25: $50 \mathrm{~kg}$ $\mathrm{N}$ and $\mathrm{P} \mathrm{ha}^{-1}$ significantly increase oil yield than the combination of $\mathrm{RDF}+\mathrm{FeSO}_{4}$ and control. As $\mathrm{Zn}$ play special role in oil seed crop to activate the enzymes for biosynthesis of oil.

\section{Protein content}

Ramlal et al., (1990) ${ }^{[25]}$ reported that increase in pod yield, oil and protein content of groundnut due to the application of zinc sulphate. Malewar et al., (1992) ${ }^{[14]}$ studied on inorganic mineral matter and quality of grains as influenced by zinc levels in peanut cultivars, reported that the Zinc application up to $20 \mathrm{~kg}$ ha'1 improve the content of ash, N, K, Ca, Zn and $\mathrm{Fe}$ in grain legume further, significant accumulation of proteins and soluble carbohydrates in peanut cultivars were recorded due to zinc application. Majumdar et al., (2001) reported that the application of $\mathrm{Zn} 25 \mathrm{~kg} \mathrm{ha}^{-1}$ to groundnut Cv.ICGS-76 significantly increased protein contents. Mirvat et al., (2006) studied the effect of phosphorus fertilizer rates (30 and $60 \mathrm{~kg} \mathrm{P}_{2} \mathrm{O}_{5} /$ ha with foliar spraying with zinc $(0,0.50$, 0.75 , and $1.00 \mathrm{~g} / \mathrm{L}$ ) on seed quality of groundnut under reclaimed sandy soil. As it gives significantly increased in protein content (26.15). These result may due to the beneficial effect of $\mathrm{P}$ and $\mathrm{Zn}$ on metabolic processes and growth which in turn reflected positively on chemical content of groundnut seed.

Bairagi et al., (2007) ${ }^{[2]}$ reported that effect of application of zinc @10 kg ha ${ }^{-1}$ and phosphatic fertilizer @ $75 \mathrm{~kg} \mathrm{ha}^{-1}$ recorded significantly maximum protein content. This may be due to zinc role in oil seed crop to activate the enzymes for the synthesis of biochemical like tryptophan result, increase in protein synthesis. And $\mathrm{P}$ being constituent of carbohydrate, protein and nucleic acid responsible for synthesis amino acids, tryptophan ultimately increases in protein content of soybean. Tathe et al., (2008) ${ }^{[38]}$ studied the effect of sulphur and zinc on groundnut in vertisol, as regards zinc application, $40 \mathrm{~kg}$ ha1 recorded significantly the highest pod yield, protein content and zinc uptake by groundnut. Nadaf and Chidanandappa (2011) ${ }^{[16,20,21]}$ reported that crude protein content oil content and oil yield of groundnut was significantly increased over the control due to application of $\mathrm{ZnSC}>4$ at three levels 5,10 and $20 \mathrm{~kg} \mathrm{ha}^{-1}$.

Reddy et al., (2011) ${ }^{[26]}$ reported that the application of macro nutrient NPK $60-80-100 \mathrm{~kg} \mathrm{ha}^{-1}$ along with four micronutrient $(\mathrm{Zn}, \mathrm{B}, \mathrm{Fe}$ and $\mathrm{Cu})$ improve quality parameter i.e. protein content $(36.57 \%)$ of groundnut were found to be the highest protein content with higher level of major nutrient as protein content is always directly proportional to nitrogen and forms the principal constituent of protein. Involvement of $\mathrm{Zn}$ in synthesis of amino acids, leading to the formation of the protein molecules. Suresh et al., (2013) ${ }^{[36]}$ studied the effect of application of $\mathrm{ZnSC}>4$ at $5 \mathrm{~kg} \mathrm{ha}^{-1}$ with recommended dose of NPK reported that significantly increase in oil content and protein content of groundnut.

\section{Conclusion}

It can be concluded that fertilizer application of zinc shows significant increase in growth parameter, nutrient concentration, uptake, availability, yield and quality of groundnut.

\section{References}

1. Arunachalam P, Kannan P, Prabhaharan J, Prabukumar G, Zadda Kavitha. Response of groundnut (Arachis hypogaea L.) genotypes to soil fertilization of micronutrients in alfisol conditions. Electronic Journal of Plant Breeding 2013;4(1):1043-1049.

2. Bairagi IV, Mahulikar DN, Hiwarale JS. Effect of zinc and phosphorus on yield, oil and protein content of soybean J Soils and Crops 2007;17(2):292-293.

3. Babhulkar BS, Bineshkar WP, Bandole SG, Balpande IK. Effect of sulphur and zinc on yield, quality and nutrient uptake by safflower in vertisol. Journal of Indian society of Soil Science 2000;48(3):541-543.

4. Bagal. Effect of zinc, iron and boron on yield, quality and nutrient uptake by groundnut. Msc. Thesis. Bhadauria H.S, Nidhi Nagar and Mudgal S.K. (2012) Effect of micronutrient cations on yield, quality and their uptake by mustard in alluvial soil. Annals of Plant and Soil Research 2006;14(2):130-132.

5. Chitdeshwari T, Poongothai S. Yield of groundnut and its nutrient uptake as influence by zinc, boron and sulphur. Agricultural science Digest 2003;23(4):263-266.

6. Elayraja D, Singaravel R. Zinc and Boron application on groundnut yield and nutrient uptake in costal sandy soils, An Asian Journal of soil science 2012;7(1):50-53.

7. Elayraja D. Response of groundnut to zinc boron and organics on the yield and nutrient availability in costal 
sandy soil. International Journal of Chemistry 2014;5:1623.

8. Gowthami VS, Ananada N. Dry matter production, yield and yield component of groundnut (Aracis hypogaea L.) genotypes as influenced by zinc and iron through fertifortification. Indian Journal of Agricultural Research 2017;51(4):339-344.

9. Krishnappa M, Srinivasan CN, Sastry JA. Effect of macro and micronutrients on oil content in groundnut. University of Agricultural Sciences (Bangalore) 1994;23(9):107-108.

10. Kumbhar CS, Indulkar BS, Wagh CB. Effect of micronutrients application on availability of $\mathrm{Zn}, \mathrm{Fe}$ and $\mathrm{B}$ of sunflower (helianthus annus 1.) in Inceptisol. International Journal of Current Microbiology and applied Science 2017;6(11):438-442.

11. Laharia GS, Hadole SS, Meena SM, Aage AB. Interactive effect of phosphorus and zinc on nutrient uptake and nutrient use efficiency of soybean. International Journal of Tropical agriculture 2015;33(4):3731-3735.

12. Maharnor RY, Indulkar BS, Kadam DV, Kadam VS, Patil NM. Effect of different levels of zinc on growth parameter viz. root length and root nodulation and nutrient availability viz. NPK and $\mathrm{Zn}$ of groundnut on Inceptisol. Journal in science, agriculture \& engineering 2018;7:2277-7601.

13. Maharnor RY, Indulkar BS, Lokhande PB, Jadhav LS, Padghan AD, Sonune PN. Effect of different levels of zinc on yield and quality of groundnut (Arachis hypogea L.) in Inceptisol. Journal of Current Microbiology and applied Science 2018;6:2843-2848.

14. Malewar GU, Indulkar BS, Takankhar VG. Root characteristics and yield attributes as influenced by zinc levels and groundnut varieties. Annals of Agricultural Research 1993;14(4):478-481

15. Meena S, Malarkodi M, Shenthilvalavan P. Secondary and micronutrient for groundnut. Agricultural Review 2007;28(4):295-300.

16. Nadaf SA, Chidanandappa HM. Effect of zinc and boron on distribution and contribution of zinc fractions to total uptake of zinc by groundnut (Arachis hypogaea L) in sandy loam in soils of Karnataka. Current Advance in Agriculture science 2015;7(1):29-32.

17. Miravat E, Gobarah Magada, Mohamed H, Tawfik MM. Effect of Phosphorus fertilizer and foliar spraying with zinc on growth, Yield and Quality of groundnut under reclaimed sandy soils. Journal of Applied Science Research 2006;2(8):491-496.

18. Mondal SK, Poi SC. Effect of micronutrient on nodulation, N2-fixation and yield of soybean, Glycine $\max ($ L.) Merrill in lateritic acid soil of west Bengal. Journal of Oilseed Research 2006;23(2):364-365.

19. Noman Heba Mohamed, Rana DS, Rana KS. Influence of sulphur and zinc levels and zinc solubilizer on productivity, economics and nutrient uptake in groundnut \{Arachish ypogaea L). Indian Journal of Agronomy 2015;60(2):301-306.

20. Nadaf SA, Chidanandappa HM. Content and uptake of macronutrients by groundnut (Arachis hypogaea L) as influenced by soil application of zinc and boron in sandy loam soils of Karnataka, India. Legume Research 2015;38(3):363-366.

21. Nadaf, Chidanandappa. Effect of Zinc and Boron Soil
Application on Growth and Yield parameters of groundnut \{Arachis hypogaea L.). Green Farming 2011;2(6):665-667

22. Rabari KV, Patel KM, Patel BT, Desai NH. Influence of ferros sulphate and zinc sulphate on pod yield of groundnut. International Journal of Agriculture Sciences 2018;10(7):5725-5726.

23. Rahevar HD, Patel PP, Patel BT, Joshi SK, Vaghela SJ. Effect of FYM, iron and zinc on growth and yield of summer groundnut \{Arachis hypogaea L) under north Gujarat Agroclimatic conditions, Indian. J Agricultural Research 2015;49(3):294-296.

24. Rai SK, Deeksha Chark, Rajeev Bharat. Scenario of oilseed crops across the globe. Plant Archives 2016;16(1):125-132.

25. Ramlal, Baldeo Singh, Mukul Rani Mashih. Effect of zinc on yield, oil And protein content of groundnut. Department of soil science, Agricultural Research Station, Jaipur 3020181990.

26. Reddy ST, Reddy DS, Reddy GP. Effect of different nutrient management practices on yield of post rainy season groundnut (Aracis hypogaea L.). Journal of oilseeds 2011;28(1):54-56.

27. Sara M, Shafarodi SB, Sadeghi SM. The evaluation on effect of nitrogen fertilizer and chelated zinc on the yield of peanut (Arachis hypogaea L.). Indian Journal of Fundamental and Applied Life Science 2013;3(4):95103.

28. Saini JS, Tripathi HP, Dwivedi RS, Randhawa NS. Effect of micronutrients on the yield and quality of groundnut (Arachis hypogaea L.). Journal of Research, Punjab Agricultural University 1976;12(3):224-227.

29. Saha Bholanath, Saha Sushant, Saha Ritam, Hazra GC, Mandal Biswapati. Influence of $\mathrm{Zn}, \mathrm{B}$ and $\mathrm{S}$ on the yield and quality of groundnut (Arachis hypogaea L). Legume Research 2015;38(6):832-836.

30. Singaravel R, Parasath V, Elayaraja D. Effect of organics and micronutrients on the growth, yield of groundnut in coastal soil. International of Agricultural Science 2006;2(2):401-402.

31. Saren BK, Sarkar K. Response of groundnut (Aracis hypogaea L.) under different levels of irrigation and zinc. Journal of Oilseeds Research 2007;24(1):94-95.

32. Singh YP, Mann JS. Interaction effect of sulphur and zinc in groundnut Arachis hypogaea L.) Indian Journal of Agronomy 2007;52(1):70-73.

33. Sonawane BB, Nawalkar PS, Patil VD. Effect of micronutrient on growth and yield of groundnut. J Soils and Crops 2010;20(2):269-273.

34. Sharma SK, Jain NK, Upadhyay B. Response of groundnut to balanced fertilization under sub-humid southern plain zone of Rajasthan. Legume Research 2011;34(4):273-277.

35. Singh YP, Smita Chaudhary. Direct and residual effect of $\mathrm{Zn}$ application in groundnut- wheat cropping system in Alfisols. Journal of oilseed Research 2006;23(2):205208.

36. Suresh G, Murthy IYLN, Sudhakara Babu SN, Varprasad KS. An overview of zinc use and its management in oilseed crops. Anopes journal published by ICR1SAT 2013.

37. Tripathy SK, Patra AK, Sawmi RC. Effect of micronutrients on nodulation growth, yield and nutrient uptake of summer groundnut. Annals Agricultural 
Research 1999;20(4):439-442.

38. Tathe AS, Patil GD, Khilari J. Effect of sulphur and zinc on groundnut in vertisols. An Asian J of Soil Science 2008;3(1):178-180.

39. Vyas MD, Jain AK, Tiwari RJ. Long terra effect of micro-nutrients and FYM on yield and nutrient uptake by soybean on a typic chromustert. Journal of Indian society of Soil Science 2003;50(1):45-47.

40. Thakur BD, Shaikh FG, Thombre PS, Kalegore NK. Response of winter season groundnut (Aracis hypogaea L.) to iron and zinc application. Journal of Oilseeds Research 2010;27(2):181-182. 